\title{
Advancements and Use of OMIC Technologies in the Field of Bioleaching: A Review
}

\author{
Archana Pattanaik ${ }^{1}$, D P Krishna Samal ${ }^{2}$, Lala Behari Sukla 1,*iD, Debabrata Pradhan ${ }^{1(D)}$ \\ 1 Biofuels and Bioprocessing Research Center, ITER, Siksha 'O' Anusandhan (Deemed to be University), Bhubaneswar- \\ 751030, India \\ * Correspondence: suklalb@yahoo.co.in;
}

Scopus Author ID 6603724593

Received: 1.09.2020; Revised: 8.10.2020; Accepted: 11.10.2020; Published: 13.10.2020

\begin{abstract}
Bioleaching is an environmentally safe as well as economically feasible alternative to the conventional process of metal extraction from low-grade ores. It involves the recovery of metals through microbial oxidation of metallic and/or sulfuric compounds. Wide varieties of acidophilic microbes present in the mining sites, which are necessary to decrease the $\mathrm{pH}$, eventually contribute to the biomining efficiency. Ongoing development and recent advanced techniques will ensure that the implementation of genetic engineering might improve the extraction rate within less time period. The use of OMIC (genomics, proteomics, metabolomics, etc.) techniques in bioleaching is gaining interest worldwide. In the last decade, a number of studies have been carried out for the determination of bioleaching diversity, development of conceptual and functional metabolic models, analysis of microbe-mineral interaction, etc. by using various OMIC technologies. These technologies are used to improve the understanding of various microbial activities during the bioleaching process, which helps in the development of industrial-scale bioleaching process.
\end{abstract}

Keywords: Bioleaching microorganisms; Commercial bioleaching; Heap leaching; Acidithiobacillus ferrooxidans; Genomics; Proteomics.

(C) 2020 by the authors. This article is an open-access article distributed under the terms and conditions of the Creative Commons Attribution (CC BY) license (https://creativecommons.org/licenses/by/4.0/).

\section{Introduction}

Bioleaching is known as the conversion of an insoluble metal into a soluble form involving microbes. Metal sulfides are oxidized to metal ion and sulfate or sulfur compound by a number of acidophilic sulfur-oxidizing chemolithotrophs, which are mostly thermophilic in nature, for instance, Acidithiobacillus thiooxidans, Acidithiobacillus ferrooxidans, Pseudomonas aeruginosa, Chromobacterium violaceum, L. Ferriphilum, Sulfobacilli, Aspergillus, Penicillium, etc. These potential microbes have the ability to create an acidic environment that is suitable for metal extraction. Due to the implementation of microorganisms in bioprocessing, bioleaching is regarded as a cost-effective and environmentally friendly process. The various industrial process of bioleaching like dump leaching, heap leaching, insitu leaching is being employed in mining industries [1]. Heap leaching is a conventional and environmentally preferred mechanism over other leaching processes. A considerable number of research works are going on by the scientists for increasing application of bioleaching in diverse industrial fields. The enhancement in metal extraction efficiency of commercial bioleaching processes requires advanced designing, proper controlling, and process optimization. To achieve this, an in-depth understanding of microbial physiological processes involved in bioleaching is foremost necessary. In the recent past, the use of OMIC technologies 
has widened our knowledge of various microbial phenomena that occur during the bioleaching process. Applications of these technologies help in identifying new bioleaching microbial consortia in extreme environments as well as to study the molecular adaptation to their environment [2]. Here authors have briefly reviewed some of the recent developments in industrial-scale process designing as well as a detailed understanding of microbial activities involved in bioleaching processes with the aid of OMICS.

\section{History and evolution of bioleaching}

The Bioleaching process had been unknowingly used to extract metals for decades. The leaching of copper from its sulfide ore has been practiced by the Chinese back in 100-200 BC, but after the 2nd century, these processes were also well-known in Europe and some counties of Asia. The Rio Tinto mine in Spain and the Harz mountain areas in Germany have a vital role in the history of biomining because in the 16th-century dump/heap leaching extraction process was performed there. Heap leaching of copper with oxide ores has been practiced for several decades. In 1557, a book named De Re Metallica, written by Georgius Agricola, mentioned heap leaching process can be completed within 40 days [3]. Pyrite containing some copper sulfide left exposed, and during the rain, oxidation of copper took place. Metal solubilization in the association with specific microorganisms was known to be evidently used after the 1940s. In 1887, Pressure leaching for the extraction of metals from different ores was found to be carried out in France by L. LeChatelier and K.J. Bayer for extraction of $\mathrm{Al}(\mathrm{OH})_{3}$ and $\mathrm{Al}_{2} \mathrm{O}_{3}$ from bauxite ores with $\mathrm{Na}_{2} \mathrm{CO}_{3}$ and $\mathrm{NaOH}$ and the Bayer process is still used since the 1890's for beneficiation of bauxite [4]. However, bio-beneficiation of low-grade bauxite using microorganisms has been reported as a promising beneficiation process by several researchers [5]. Cyanidation is extensively used as one of the control technology for the recovery of precious metals like gold and silver. In 1887 J.S. MacArthur first, apply the cyanidation method for leaching of gold and silver from their ores, and during the period of 1900-1920, the application of this process increased greatly. At Cortez in 1969, gold and silver heap leaching was first started, and in the 1980s, bioleaching of gold, silver, and copper has been practiced commercially. The biooxidation process started in the late 1970s at GENCOR process research in Johannesburg, South Africa. Gold is extracted from metallic sulfides by the bio-oxidation method.

\section{Commercial bioleaching processes}

Different commercial bioleaching processes are being used in the extraction of precious metals such as copper, cobalt, uranium, and gold, as well as in the beneficiation of low-grade ores.

\subsection{Dump leaching.}

Dump leaching is the oldest, simplest, and low-cost industrial process for extracting copper from ores [6]. It is a technique that involves uncrushed waste rock piled up in huge dumps. Promoting the growth of acidophilic microorganisms and maintaining the low $\mathrm{pH}$, diluted sulfuric acid or acidified ferric sulfate solution (as a lixiviant) is showered down in dumps. The enriched runoff is collected at the base of the dump and pumped out for the recovery. 


\subsection{Heap leaching.}

Heap leaching is an on-site leaching technique where crushed ore stacked on an impermeable lined pad. The acid runoff from the heap ores is collected from drains at the bottom. The preliminary methods included in heap leaching processes are crushing and spreading the ore (over HDPE or PVC geo-membrane line pads), spraying the leaching solvent (sulfuric acid, cyanide). Bioleaching operations in a heap are generally carried out by indigenous microorganisms forming biofilms. The heterogeneous environment of heap bioreactors influences the growth of the bioleaching microorganisms. Hence, a great diversity of microorganisms are present within the heap at different stages of bioleaching operation. A few examples of microbial diversity identified in heap operations are presented in Table 1. Then metal recovery operations have been performed for the low-grade ores by precipitation, smelting, absorption, and electro-winning. The heap leaching industry includes two main areas: leaching of secondary copper ores that contain copper sulfides ( chalcocite $\left(\mathrm{Cu}_{2} \mathrm{~S}\right)$ and covellite $(\mathrm{CuS})$ ) and the pretreatment of gold-bearing ores where the gold is occluded in sulfide minerals $[7,8]$. Heap leaching has a lot of benefits over other conventional mining processes involving low operating costs, less energy-consuming, provide more regulation of biological, chemical, engineering factors, furthermore prevent pollution and loss of leach solution. So the application of heap leaching in industrial mining sectors is relatively higher than the other mining activities. Since 2000, the application of the heap mining method by employing sulfuric acid as the lixiviant gained acceptance for the recovery of precious metals from low-grade ores. Pradhan et al., 2008, have discussed different important aspects of the chalcopyrite bio heap leaching process [9]. Sukla et al., 2009, performed heap bioleaching of low-grade copper sulfide ore in a 15 and 30-ton scale at CSIR-IMMT, Bhubaneswar. This experiment resulted in the dissolution of $0.09 \%$ of copper from the ore per day [10]. Panda et al., 2012, carried out a 1000 tons scale bio heap leaching of low-grade chalcopyrite using a mixed culture of acidophilic bacteria for a period of 383 days. This heap bioleaching process resulted in the copper recovery of $30 \%$ [11].

Precious metals like gold, silver, zinc, platinum, and other base metals from oxide ores are recovered by heap mining $[12,13]$. In the gold heap leaching method, a diluted cyanide solution is applied for gold recovery, and silver removal is obtained from pregnant effluents by carbon adsorption-desorption process [14]. Biooxidation in a heap is a very slow process. It takes several months to be completed, but the capital costs are very low. 50-70\% of gold recovery was observed using this process. Applying heap mining technology in recent years, approximately three million copper has been extracted, which is $16 \%$ of total copper production worldwide [15]. At $65^{\circ} \mathrm{C}, 93 \%$ Copper, $75 \% \mathrm{Ni}$ and $53 \%$ Co were extracted by bio heap Sequential leaching in the 304 days. By cyanide leach experiment, 57.8\% Pt, 99.7\% Pd, and $90.3 \% \mathrm{Au}$ was extracted at $50^{\circ} \mathrm{C}$ in 60 days [16]. 49-61\% gold recovery was achieved by heap biooxidation method at $81^{\circ} \mathrm{C}$ in 150 days [17]. For permanent heap operation in the gold mining process, two similar leaching pads are used.

During the past few years, applications of rare earth elements increased significantly in electronics, satellites, and automobiles. Therefore recovery of these critical elements from various wastes through heap mining is required. It is possible to recover heavy rare earth elements like Y, Eu, Dy by heap leaching, bio-oxidation, and solvent extraction. It was reported by Pingiture, 2016 that $91.3 \%$ and $87.2 \%$ Yttrium and Dysprosium were leached via heap leaching [18]. 
Table 1. Examples of microbial diversity identified in heap operations

\begin{tabular}{|c|c|c|}
\hline Heap leaching operations & Microbial Diversity & References \\
\hline Chalcocite & $\begin{array}{l}\text { A. caldus, L. ferriphilum, Sulfobacillus } \\
\text { spp., Ferroplasma cupricumulans }\end{array}$ & {$[108]$} \\
\hline Refractory gold ores & $\begin{array}{l}\text { A. ferrooxidans, Leptospirillum-like, } \\
\text { Sulfobacillus spp. }\end{array}$ & {$[144]$} \\
\hline Chalcopyrite overburden & $\begin{array}{l}\text { A. thiooxidans, A. ferrooxidans, } \\
\text { Acidiphilium cryptum }\end{array}$ & {$[1]$} \\
\hline Secondary copper sulfide ore & $\begin{array}{l}\text { Acidithiobacillus spp., Leptospirilum } \\
\text { spp., Ferroplasma spp., } \\
\text { Ferrimicrobium spp., Sulfobacillus } \\
\text { spp., A. albertensis }\end{array}$ & {$[145]$} \\
\hline
\end{tabular}

\subsection{In situ leaching.}

Another industrial bioleaching method is in situ leaching, also called underground leaching. It is a technique where ores need not be removed from the mining ground. Several wells are arranged in a series. The aqueous solution containing microorganisms introduced through drill passages with ore. The most important limitation of underground leaching is the slow rate of reactions. Above 30 years, this scavenger technology is used to extract uranium and copper from depleted mining areas. In situ mining was used widely in Canada in the 1970s to recover uranium from deep mines [19].

\subsection{Tank leaching.}

Tank leaching operates in a semi-closed system within a designed reactor or in a set of tanks. It is a continuous process, therefore more expensive and has high capital costs. The enhanced recovery of copper in the stirred tank reactor has been reported [20]. The extraction of cobalt from pyrite concentrate has also been reported [6, 21, 22]. In Chile, the biomining of chalcopyrite has been detected at temperature $80^{\circ} \mathrm{c}$ using pilot stirred tank mining [23]. Biooxidation with stirred tanks is a high operating cost comparing to the other processes. It is mostly applicable for higher concentrate gold-bearing ores in which the fine gold particles are enshrouded by sulfide minerals (mainly arsenopyrite and pyrite).

\section{Recent developments in bioleaching}

Applications of solar energy, microwave, and ultrasound treatment have improved the extraction of metal values from low-grade ores through the bioleaching process. Solar energy is an important renewable energy source. Due to its lower maintenance, short operational period, and minimum cost, the use of this alternative source in the biomining process is increasing lately. Solar energy cells in heap leaching help in raising the temperature of the lixiviant; thus, favorable conditions are being created for extreme thermopiles to achieve better extraction. It has been reported that solar thermal energy in the mining sector boosts the recovery rate of copper from $67 \%$ to $85 \%$ [24]. In Chile, solar systems have already been installed in some industrial mining areas for electro-winning operations. Microwave pretreatment generates crack on the surface area of the ores that have led to ore strength reduction, weaken of coarse particle. Pre-treated ores showed improved recovery in comparison with untreated. Up to 6-15\% of the copper recovery in bioleaching is improved by 
microwave treatment [25]. An experimental study was conducted for bioleaching of low-grade chalcopyrite using a mixed culture of meso-acidophilic microorganisms in the presence of acidprocessed waste newspaper. This study, for the first time, reported that the presence of acidprocessed waste newspaper enhanced the bio-recovery of copper up to a maximum of $99.13 \%$ [26]. Some experimental studies also described that the effect of ultrasound pretreatment on nickel leaching using A.niger 95\% nickel could be leached along with $12.5 \%$ of iron from lateritic ore [27]. The application of Dissimilatory Iron Reducing Bacteria (DIRB) has been reported to enhance the recovery of $\mathrm{Ni}$ and Co from lean lateritic nickel ore [28].

The tremendous increases in electronic industries and IT sectors have led to surplus ewastes. E-waste management without causing a risk to human health as well as less damaging the environment, the greatest challenge faced by every country. These e-wastes are a rich source of metals such as gold, silver, cobalt, palladium, rhodium, etc. Therefore recycling of e-waste is immensely required to meet the demand for these critical materials in the future. Bioleaching is gaining an increasing interest in recovering precious metals from various ewastes in an eco-friendly manner [29]. Acidithiobacilli have the ability to leach more than $90 \%$ of copper and nickel from e-scraps. It has been demonstrated that using potential microorganisms like C. Violaceum, Aspergillus niger, Penicillium simplicissimum gold can be extracted from the waste printed circuit boards [30]. Massive research work is being carried out for the application of bioleaching techniques for the removal of toxic heavy metals (bioremediation) from solid wastes generated due to different industrial activities [31-34].

\section{Bioleaching microorganisms}

Majorly two types of microorganisms are involved in heap leaching reactions, which are iron-oxidizing chemolithotrophs and sulfur oxidizing chemolithotrophs [35]. They have the ability to fix carbon dioxide from the atmosphere and utilize it as an energy source. Using iron and reduced organic sulfur as an electron donor and oxygen as an electron acceptor, these microbes grow autotrophically in mining areas. Generally used microorganisms which are engaged in metal solubilization are mostly thermophilic in nature.

Mineral decomposition and types of microbes involved in mining depend on different temperatures and $\mathrm{pH}$. According to the deviation of temperature, the distribution of microorganisms also varied. So different species of microorganisms work at mineral decomposition techniques; they are mesophilic microbes (optimal temperature is between 30 $\left.35^{\circ} \mathrm{C}\right)$, moderate thermophilic microbes $\left(45-55^{\circ} \mathrm{C}\right)$, and extreme thermophilic microbes $\left(70^{0}\right.$ C above) [36].

Acidithiobacillus ferrooxidans was the first acidophilic iron- and sulfur-oxidizing bacterium isolated by Temple and Colmer, 1951 [37]. Later investigations into bioleaching Leptospirillum ferrooxidans [38], Acidithiobacillus thiooxidans, and Acidithiobacillus caldus had been reported [39, 40]. Acidithiobacillus genera are rod-shaped; gram-negative non-sporeforming bacteria also survive under anaerobic conditions. Common Acidithiobacillus species are Acidithiobacillus thiooxidans, Acidithiobacillus ferrooxidans, Acidithiobacillus caldus, Acidithiobacillus acidophilus, Acidithiobacillus concretivorus, Acidithiobacillus albertis, and Acidithiobacillus prosperus. These can oxidize elemental sulfur and generate sulfuric acid that can reduce the medium $\mathrm{pH}$ up to 1 to provide suitable conditions for the bioleaching operations. Acidithiobacillus ferrooxidans converted soluble ferrous iron to ferric iron at $40^{\circ} \mathrm{C}$, lowering the $\mathrm{pH}$ up to $1.8-2.0$ [41-43]. It is considered as the model for biomining organisms. 
Acidithiobacillus thiooxidans are mesophilic, but more acid-tolerant can survive in $\mathrm{pH} 0.5$ [42, 44]. Ferroplasma acidiphilum growing optimally at $33^{\circ} \mathrm{C}-45^{\circ} \mathrm{C}$ and $\mathrm{pH}$ range between 1.7 1.3 [45]. Leptospirillum ferrooxidans is obligatory chemolithotroph and a dominant iron oxidizer. This species is highly acid-tolerant in nature (optimum $\mathrm{pH} \gg 1.5-1.8$ ). $L$. thermoferrooxidans reported to grow at $45^{\circ} \mathrm{C}$, and L. Ferriphilum and Sulfobacilli species are moderately thermophilic (operated at $40^{\circ}-60^{\circ} \mathrm{C}$ ) [46, 47]. Sulfolobus metallicus and Metallosphaera sedula are thermophilic in nature. They are able to oxidize various minerals at temperatures of $68^{\circ} \mathrm{C}$ and $80^{\circ}-85^{\circ} \mathrm{C}$ within a $\mathrm{pH}$ range of about 1.3-1.7 and1.0-4.5 accordingly [48, 49]. Hydrothermophillic archaea such as Acidianus brierleyi and Acidianus infernus have been reported, which can endure the optimum temperature $70^{\circ} \mathrm{C}-90^{\circ} \mathrm{C}$ and the optimum $\mathrm{pH}$ 1.5-2.0 [35, 50]. Aspergillus and Penicillium genera are generally found to be the most effective fungal species used in biomining [51-53]. Liao et al. 2019 studied the effect of microbial consortia designing on the bioleaching of low-grade metal sulfides and proposed a new strategy for the bioleaching of tailings. According to this newly proposed strategy, iron oxidizers should be added at the initial and middle stages, and sulfur oxidizers should be added towards the end of the bioleaching process [54].

Removal of the precious metals from the e-scrap by using microorganisms such as bacteria, fungi is now in demand. Cyanogenic microbes, for instance, Pseudomonas fluorescens, Pseudomonas aeruginosa, Chromobacterium violaceum, Pseudomonas plecoglossicida have been reported in gold leaching from e-waste [30]. Some organic and inorganic acids are secreted by these thermophilic microbes, and fungus engages in bioleaching processes such as citric, lactic, gluconic, oxalic, as well as some enzymes [55]. Cyanogenic microbes such as Pseudomonas fluorescens, Pseudomonas aeruginosa, Chromobacterium violaceum have abilities to produce cyanide ions that dissolve the gold in between their metabolic activities. $62 \%$ of copper was extracted within 30 days by a mixed culture composed of A. thiooxidans and Leptospirillum ferrooxidans [56].

\section{Bioleaching mechanism}

The bioleaching mechanism has been studied thoroughly in the past. Some earlier studies have described the bioleaching process takes place via the direct mode (involves the transfer of electrons directly from mineral to the cells attached to its surface) or indirect mode (involves metal sulfide dissolution by metal sulfide oxidizing agent, i.e., $\mathrm{Fe}^{3+}$ ions) [21]. As no direct electron transfer between metal sulfide and the adhered cells has been described, a direct leaching process seems not to occur [57]. For a better description, the bioleaching processes by attached cells and planktonic cells, the more appropriated proposed terms are "contact leaching" and "non-contact leaching," respectively [58]. The term "cooperative leaching" has been proposed to describe the dissolution of sulfur intermediates, sulfur colloid, etc. by planktonic cells $[35,59]$.

The chemical mechanism involved in the microbial dissolution of metal has been studied extensively [60]. On the basis of acid solubility and mineralogy, sulfide minerals dissolution has been described to occur via two pathways termed as thiosulfate pathway and polysulfide pathway [57, 61, 62]. Dissolution of acid non-soluble metal sulfides has been reported to occur via the thiosulfate pathway. $\mathrm{FeS}_{2}$ is the most studied metal sulfide for the oxidation of sulfide minerals [63-65]. In this pathway, the sulfur moiety of $\mathrm{FeS}_{2}$ is oxidized to soluble sulfur intermediates by the initial attack of $\mathrm{Fe}^{3+}$ ions (oxidizing agent) through the extraction of several electrons. Thiosulfate has been reported as the first soluble sulfur 
intermediate $[66,67]$. Thiosulfate is then oxidized to tetrathionate, which is further oxidized to trithionate, pentathionate, elemental sulfur, and sulfite $[64,65,68]$. Bioleaching experiment with Acidithiobacillus ferrooxidans provides conformation of this pathway by the determination of the stable isotope of sulfur and oxygen in the reaction product [69].

The polysulfide pathway has been proposed for the dissolution of acid-soluble metal sulfides such as chalcopyrite, sphalerite, pyrrhotite, etc. In this pathway, apart from Fe(III) ion attack, these metal sulfide can also be dissolved by protons. Here, the oxidation of acid-soluble metal sulfide results in the formation of elemental sulfur through a series of reactions via polysulfides under acidic conditions [70-73]. The elemental sulfur formed, being chemically inert, can be oxidized by biological means to sulfuric acid. The results of the bioleaching experiment of chalcopyrite and sphalerite oxidation with Acidithiobacillus ferrooxidans showing the presence of a stable isotope of sulfur and oxygen in the reaction product supported the polysulfide pathway $[74,75]$.

\subsection{Role of microorganisms in bioleaching.}

Microorganisms play a significant role in both the pathways by regenerating ferric iron for the oxidative attack [76]. These acidophilic iron oxidizers such as Acidithiobacillus ferrooxidans and Leptospirillum ferrooxidans are reported to bring about oxidation of ferrous iron $\left(\mathrm{Fe}^{2+}\right)$ to ferric iron $\left(\mathrm{Fe}^{3+}\right)$. In the polysulfide pathway, another important function of microorganisms (acidophilic sulfur oxidizers) is the transformation of elemental sulfur to sulfuric acid. The proton regenerated by sulfuric acid production from elemental sulfur is required for initial leaching processes. As the elemental sulfur is chemically inert to the abiotic oxidation at low $\mathrm{pH}$ and its accumulation upon the metal sulfide hinders the process of metal leaching $[40,77]$.

\subsubsection{Iron oxidation pathway.}

One of the main characteristic features of biomining microbes is their capability to derive energy from the oxidation of iron and/or sulfur. The iron oxidation pathway has been extensively studied for different biomining microbes [78]. In the case of A. ferrooxidans the oxidation of $\mathrm{Fe}(\mathrm{II})$ to $\mathrm{Fe}(\mathrm{III})$ occurs at the outer membrane. The respiratory chain consists of a high molecular weight cytochrome oxidase (Cyc 2) (the initial electron acceptor present at the outer membrane), blue copper protein rusticyanin (RusA), another cytochrome (Cyc 1), and an aa3 type cytochrome oxidase (which catalyzes the reduction of $\mathrm{O}_{2}$ ) $[78,79]$. The electron from $\mathrm{Fe}$ (II) is first trapped by Cyc 2, which is then transferred to Rus A. From rusticyanin, an electron can be transported either through a 'downhill' or an 'uphill' pathway. In the downhill pathway, an electron from Rus A is transported to membrane-bound cytochrome (Cyc 1) and then to aaz type cytochrome. This pathway is meant for ATP synthesis $[60,78,79]$. In 'uphill' pathway, the electron from Rus A is transported through a membrane-bound cytochrome (Cyc A1), bc1 complex, and membrane-associated ubiquinones to NADH-1 complex, which catalyzes the $\mathrm{NAD}^{+}$reduction to NADH. A. ferrooxidans can also oxidize $\mathrm{Fe}^{2+}$ through a second pathway, which consists of a high potential iron-sulfur protein Iro and a rusticyanin isoenzyme Rus B [80]. A complex respiratory chain for iron oxidation has been reported for Leptospirillum sp. than A. ferrooxidans consisting of some additional components like cytochrome $\mathrm{C}$ oxidase, bd-quinol oxidase, and BC1 complexes [81]. In Ferroplasma, an electron from $\mathrm{Fe}^{2+}$ may be transported by a copper protein sulfocyanin and $\mathrm{cbb}_{3}$ as a terminal electron acceptor [82]. In the case of Metallosphaera sedula and Sulfolobus metallicus electron 
is transported through a different pathway with an electron transport chain consisting of cytochrome b, ferredoxins, heme copper oxidase, and some proteins. These are reported to be encoded by a cluster of fox genes present in the genome of the organisms [83, 84].

\subsubsection{Sulfur oxidation pathway.}

The sulfur oxidation pathway of different acidophilic sulfur-oxidizing bacteria and archaea seems to be different. The oxidation of elemental sulfur, sulfide, and RISC (reduced inorganic sulfur compound) is carried out by several enzymes such as sulfur dioxygenase, sulfate: oxidoreductase, sulfide: quinone oxidoreductase, thiosulfate quinone oxidase, tetrathionate hydrolase, and rhodanese, which have been found in A. ferrooxidans genome [78]. Rohweder and Sand, 2003 proposed a model for the oxidation of elemental sulfur and RISC by A. ferrooxidans, A. thiooxidans, and Acidiphilium acidophilium (76 characterizations). According to this model, extracellular elemental sulfur is first transported to the periplasm where it gets oxidized to sulfite and sulfate by sulfur dioxygenase and sulfite oxidoreductase, respectively. The electrons are transferred through a bd type oxidase or a ba3 type oxidase via the bc1 complex $[85,86]$.

\subsubsection{Microbial - mineral interaction.}

Previous studies have reported that adherence of bioleaching bacteria A. ferrooxidans to mineral sulfide surface occurs by means of extracellular polymeric substance (EPS) forming biofilms $[60,87,88]$. Organized layers of bacteria that get attached to the mineral surface by means of EPS matrix are described as biofilms. The contact between mineral surface and bacteria stimulates the synthesis of EPS by the bacterial cells $[88,89]$. It is reported that the composition of EPS varies depending upon mineralogy of the mineral surface upon which the bacterial cells will adhere. The EPS of A. ferrooxidans growing upon $\mathrm{FeS}_{2}$ are composed of glucuronic acid, C12-C20 saturated fatty acids, sugars, and $\mathrm{Fe}^{3+}$ ions, while the EPS composition of A. ferrooxidans cells growing upon elemental sulfur include uronic acid, more fatty acid than the earlier case, and sugars [90]. The EPS matrix provides an environment for intercellular interactions between bacteria, as well as for oxidation of Fe(II) takes place [91]. Some of the important physiological responses of biomining microbes for microbial mineral interaction are chemotaxis, quorum sensing, and biofilm formation. A. ferrooxidans and $L$. ferrooxidans are reported to have chemotaxis response towards pyrite and thiosulfate, respectively [92-94]. Quorum sensing is a phenomenon where bacterial cells communicate with each other through acyl-homoserine lactone molecules to coordinate their behavior. A quorum sensor signal molecule (AI) and a quorum-sensing locus (afeIR) were identified in $A$. ferrooxidans. A study reported the expression of afe $I$ and afe $R$ in sulfur grown A. ferrooxidans cells. Overexpression of afe I was reported in A. ferrooxidans cells growing on solid elemental sulfur, forming biofilms $[95,96]$. This result suggests the possible role of quorum sensing in EPS production and biofilms formation. Another QS (AI) synthase has been reported in $A$. ferrooxidans [97]. A c-di-GMP (3',5'-cyclic diguanylic acid) pathway has been reported in $A$. ferrooxidans suggesting its involvement in EPS synthesis and biofilm formation [98]. A functional operon involved in EPS synthesis has been reported in A. ferrooxidans [99]. 


\section{Current scenario of OMICS approach in biomining}

\subsection{Impacts of genomics.}

The use of OMICS (genomics, metagenomics, proteomics, metaproteomics, etc.) enables the discovery of new non-cultivable biomining microorganisms and a better understanding of their metabolic pathways involved in biomining processes as well as several adaptive responses to their environment (Figure 1) [100]. A. ferrooxidans is the most studied biomining microorganism and is the first biomining microorganism to have its genome sequenced by TIGR [101]. Among the biomining microorganisms, 36 archeal and 55 bacterial complete genome sequences are currently available to NCBI database and are accessible [77, 102]. The application of omics has greatly influenced our knowledge of biomining. Some applications of omics in the bioleaching field are given in Table 2. The main aim of genomic research has been a deeper understanding of the metabolism, which is directly involved in some of the important metabolic pathways such as iron and sulfur oxidation, quorum sensing, flagella formation, chemotaxis carbon assimilation, nitrogen fixation, and adaptation to bioleaching environment. Christel et al., 2018 presented a high quality closed genome of Leptospirillum ferriphilum $^{\mathrm{T}}$ for an in-depth understanding of its metabolic properties. By using a multi-omic approach, genes, and proteins involved in the growth of Leptospirillum ferriphilum ${ }^{\mathrm{T}}$ on chalcopyrite during bioleaching experiments have been analyzed [103]. Systems biology aims to transform genomics, transcriptomics, and proteomics data to biological knowledge for the identification of specific metabolic pathways with the aid of computational methods [104, 105].

Table 2. Applications of OMIC technologies in the bioleaching field

\begin{tabular}{|c|c|c|c|}
\hline $\begin{array}{c}\text { OMIC Technologies } \\
\text { Genomics \& Metagenomics }\end{array}$ & Molecular Techniques & Applications & References \\
\hline \multirow[t]{4}{*}{ Genomics \& Metagenomics } & $\begin{array}{l}\text { PCR, qPCR, RT PCR, } \\
\text { DGGE, DNA microarray, } \\
\text { Next Generation }\end{array}$ & $\begin{array}{l}\text { Microbial diversity study } \\
\text { of bioleaching } \\
\text { environment. }\end{array}$ & {$[108,110,114,115]$} \\
\hline & Sequencing, etc. & $\begin{array}{l}\text { In depth understanding of } \\
\text { metabolic pathways }\end{array}$ & [116-125] \\
\hline & & bioleaching microbes. & [130-134] \\
\hline & & $\begin{array}{l}\text { To study the genetic } \\
\text { variation within the } \\
\text { species. }\end{array}$ & \\
\hline Proteomics & Chromatography, SDS & Identification and & [139-142] \\
\hline & PAGE, 2D PADE, Mass & quantification of proteins & \\
\hline & $\begin{array}{l}\text { Spectroscopy, Protein } \\
\text { microarray }\end{array}$ & $\begin{array}{l}\text { involved in bioleaching } \\
\text { processes. }\end{array}$ & \\
\hline
\end{tabular}

Genome sequencing has contributed towards the determination of microbial diversity of the bioleaching environment. The developed molecular techniques such as quantitative PCR (qPCR), FISH, and DGGE has enabled researchers to explore extreme leaching environment for new biomining microbe with higher leaching potential [106, 107]. In the biodiversity of Myanmar Ivanhoe copper company heap, a heterotrophic archaea Ferroplasma cupricumulans was reported as the prevalent species by Hawkes et al., 2006 [108] which was further classified as Acidiplasma cupricumulans by Golyshina et al., 2009 [109]. In a heap at Agnes Gold Mine, Barberton, the prevalent population was identified as Sulfobacillus sp. [110]. Some researchers developed patented techniques for accurate monitoring of biodiversity during the process of bioleaching [111-113]. 


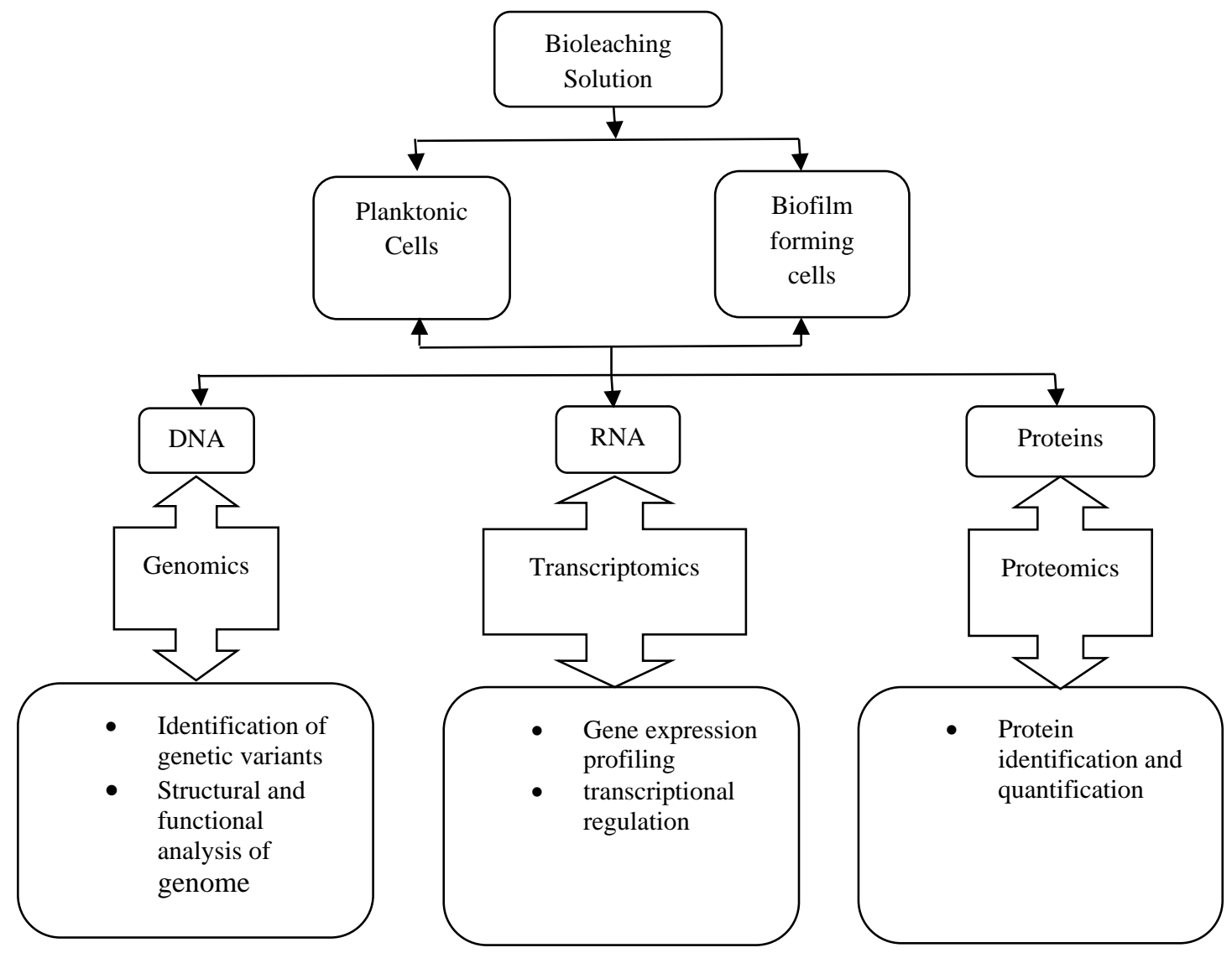

Figure 1. OMIC technology in bioleaching study

A study has been conducted using shot-gun sequencing for analysis of 16S rRNA genes to investigate the microbial diversity of the manganese mining site and their role in manganese solubilization. The result of this study shows that Proteobacteria dominates the microbial community with $42.47 \%$, followed by Actinobacteria with $23.99 \%$ within the studied manganese mining site [114]. The chemical composition and microbial diversity of two tailing basins of Panasqueira tungsten mine have been assessed to study the relationship between microbial distribution and function with the chemical variability within the two different tailing basins. The sequencing of the targeted 16S rRNA gene was carried out using the MiSeq system to identify microbial diversity. The microbial diversity of the two tailing includes members of genera Pseudomonas, Bacillus, Streptococcus, Acinetobacter, Rothia and Cellulomonas, and family Anaerolineacea. The microbiological distribution of basin 1 was related to a higher content of potassium and aluminum, whereas of basin 2 was related to As-S-Fe contents. PICRUSt software was used to predict the different microbial metabolisms that occur in this extreme environment [115].

Genome sequencing is very important in formulating a hypothesis for the reconstruction of microbial metabolic pathways in the bioleaching process (iron and sulfur oxidation pathways, biofilm formation, etc.). Acosta et al., 2005 found some genes encoding for thiosulfate-sulfur transferase-like protein for sulfur metabolism in A. ferrooxidans [116]. Bruscella et al., 2007 reported about the presence of two pet operons in A. ferrooxidans, i.e., pet II and pet I. pet II operon contains a pet II ABC gene cluster (encoding for bc 1 complex) which was co-transcribed with three more genes such as $c y c A$ (encoding for cytochrome c), $s d r A$ (encoding for a putative dehydrogenase) and hip gene. RT-PCR and Northern blotting revealed that pet $I$ was transcribed when cells are grown in an iron-containing medium while pet II was transcribed in cells grown in a medium containing iron or sulfur [117]. Quatrini et 
al., 2009 have built a metabolic reconstruction that predicted the involvement of new genes, i.e., a gene cluster including $r h d$, tus $A, d s r E, h d r C, h d r B, h d r A, \operatorname{orf} 2, h d r C, h d r B$, which encodes for 3 sulfur transferases and sat and $s d r A$ genes encoding for a heterodisulfide reductase complex [118]. More comprehensive conceptual models have been proposed for Acidilobus saccharovorans [119] and Acidianus hospitalis [120]. Moreover, a highly advance genome-scale model for A. ferrooxidans [121], L. ferrooxidans [122], A. thiooxidans [123]. Merino et al., 2015 have proposed a metabolic model for the mixed culture of L. ferriphilum and Ferroplasma acidiphilum [124]. The genomic information based conceptual models for intricate and alternative pathways of RISC oxidation have shown common features between bacteria and archaea [125]; it also revealed new metabolic characteristics and environmental adaptation in Leptospirillum ferriphilum and A. ferrooxidans [126], A. caldus [127], and Sulfobacillus thermosulfidooxidans [128, 129].

Comparative genomics has been used to study the difference between different strains of the same species. A. ferrooxidans ATCC 53993 and ATCC $23270^{\mathrm{T}}$ have 2397 common genes representing $78-90 \%$ of their genome. Due to this genomic difference, strain ATCC 53993 exhibits higher copper resistance [130]. According to Travisany et al., 2014, 75-89\% genome are common in ATC 19377, A01, and Licanantay strains of A. thiooxidans [131]. 18$28 \%$ genomes have been reported to vary within strains of the same species of Sulfolobus [132]. Valdes et al., 2010 compared the genomes of 20 bioleaching microorganisms to predict the metabolic and regulatory model for their close relatives known to occur within the bioleaching heaps [133]. Auernik et al., 2008 identified the pathways and proteins of Metallosphaera sedula involved in the bioleaching process by using comparative genomics [134]. This study reported the presence of genes related to metal tolerance, autotrophic carbon fixation, and adhesion in the genome of this archaeon. Comparison with A. ferrooxidans revealed that one putative tetrathionate hydrolase (TTH) for sulfur oxidation encoding genes are present in the genome of M. Sedula. Gene clusters homologous to fox genes of S. tokodaii and S. metallicus are also present in $M$. sedula genome.

\subsection{Impacts of proteomics.}

Proteomics plays an important role in the characterization of protein expressed in different cells or cells exposed to varied environmental conditions [96]. 2D PAGE (Polyacrylamide gel electrophoresis) coupled with mass spectroscopy (MS) is a widely used technology for proteomic analysis [135]. It has been used by several researchers to study the protein expression in A. ferrooxidans under varied growth conditions [136-138]. Ramirez et $a l ., 2004$ have characterized the changes in the synthesis of a set of proteins in A. ferrooxidans ATCC 19859 depending upon its growth in ferrous iron, metal sulfides, thiosulfate, elemental sulfur by using 2D PAGE [139]. The important role played by microbes in bioleaching is the oxidation of iron and sulfur, which are earlier demonstrated to occur in the extracellular space and periplasmic space, respectively [86]. Therefore to gather more information about the proteins involved in sulfur oxidation metabolism in A. ferrooxidans ATCC $23270^{\mathrm{T}}$, a high throughput proteomic analysis has been carried out. According to this study, 131 proteins are present in the periplasmic fraction of the bacterial cell grown in thiosulfate. $86 \%$ of the identified proteins possess predicted export signals. $45 \%$ of the total identified periplasmic proteins include cell envelope proteins, transport, and binding proteins, energy metabolism proteins, and folding proteins. Among the identified proteins, 36\% are hypothetical and unknown proteins [140]. Proteomics has helped in understanding the metal resistance 
mechanism in bioleaching microorganisms. The tolerance against high copper concentration in A. ferrooxidans ATCC $23270^{\mathrm{T}}$ has been studied using high throughput proteomic studies. This study revealed that the molecular adaptation of the bacterium against copper involves the upregulation of the RND type Cus system, increased biosynthesis of cysteine, histidine, and putative disulfide isomerase. The study also reported the downregulation of major outer membrane protein and some ionic transporters suggesting a decreased influx of metals and other cations. Moreover, rus operon encoded proteins were found to be increased in cells under copper stress suggesting their involvement in the copper resistance mechanism [141]. Bellenberg et al., 2019 investigated the molecular mechanisms involved in oxidative stress resistance and ROS detoxification in Acidithiobacillus ferrooxidans DSM $14882^{\mathrm{T}}$ cells growing on $\mathrm{Fe}^{2+}$ and biofilm cells growing upon pyrite for 5 days. By using shot-gun proteomics and compared proteomes of the two different types of cells, they identified a total of 1157 proteins. 80 proteins are reported to be involved in oxygen and metal homeostasis, repair mechanism, degradation of ROS, thiol redox regulation, and antioxidant production. They discussed the importance of globins in oxygen homeostasis and defense mechanism against oxidative stress in pyrite grew biofilm cells [142,143].

Biofilm formation is one of the most important phenomenons to occur in the bioleaching process, which is known to be mediated by EPS [60]. By using semi-quantitative shot-gun proteomics, planktonic cell and attached cells forming biofilm for $24 \mathrm{hrs}$ upon pyrite was compared. This study observed some molecular adaptations in biofilm-forming cells, such as an increase in biosynthesis of EPS, ABC transporters, efflux pumps, and proteins involved in the stress resistance mechanism. Proteins involved in osmotic and oxidative stress resistance were also found in biofilm cells. The increase in the level of Env Z protein (osmolarity sensor protein), an iron, and 2-oxoglutarate-dependent dioxygenase encoding a protein in biofilm cells have also been observed. The presence of proteins that are involved in glutathione (GSH) metabolism has also been observed in biofilm cells. Rohweder and Sand, 2003, reported the involvement of GSH in RISC oxidation and resistance against oxidative stress [85]. Thus the increased level of periplasmic GSH in cells forming a biofilm on pyrite surface suggests enhancement in RISC oxidation and oxidative stress resistance. The study also reported the increase in biosynthesis of coenzymes and cofactors in biofilm cells. This study detected 1319 proteins in biofilm cells, out of which 231 proteins are reported to be hypothetical [89].

\section{Conclusion}

For a few decades, biomining technology is increasingly being used for extracting metals from low grade and refractory ores. Heap mining, dump mining, in situ mining, and tank mining are some commercial applications of this process in the recovery of precious metals in industrial sectors. Not-only retaining of low-grade ores but e-wastes recycling, rare earth elements extraction is the significant approach in biomining sectors. The revival of valuable metals from different ores with several acidophilic sulfur-oxidizing microorganisms is demonstrated. Currently, genomic techniques are being used for monitoring of leaching diversity and reconstruction of metabolic models. Metagenomics can be used for the analysis of spatial and temporal microbial diversity during the bioleaching process through nextgeneration sequencing and development of metabolic functional models, which might be helpful in designing and controlling optimal bioleaching process. Proteomics using genomic information has impacted the understanding of microbe-mineral interactions. However, 
functional characterizations of identified proteins as well as identification of the hypothetical and unknown proteins reported during the high throughput study require some more proteomic efforts. The development of industrially relevant strains and understanding of their interaction with a mineral surface in mixed cultures is gaining interest. Moreover, the use of metabolomics might be helpful in developing biomarkers to monitor the microbial activities during the bioleaching operation. This knowledge will help in providing appropriate physiological conditions to the microbial consortia and controlling of leaching environment, which will lead to improved biomining operations.

\section{Funding}

This research received no external funding.

\section{Acknowledgments}

The authors are grateful to Prof. (Dr.) Manojranjan Nayak, President, Siksha 'O' Anusandhan University, for providing infrastructure and encouragement throughout.

\section{Conflicts of Interest}

The authors declare no conflict of interest.

\section{References}

1. Natarajan, K.A. Methods in Biohydrometallurgy and Developments: Dump, Heap, In Situ, and Stirred Tank Bioleaching. In Biotechnology of Metals, 1st ed.; Natarajan, K.A., Ed.; Elsevier, 2018; pp. 81-106. https://doi.org/10.1016/B978-0-12-804022-5.00005-0

2. Kaksonen, A.H.; Deng, X.; Bohu, T.; Zea, L.; Khaleque, H.N.; Gumulya, Y.; Boxall, N.; Morris, C.; Cheng K.Y. Prospective directions for biohydrometallurgy. Hydrometallurgy 2020, 195. https://doi.org/10.1016/j.hydromet.2020.105376

3. Kappes, D.W. Precious metal heap leach design and practice. In Mineral Processing Plant Design, Practice, and Control; Mular, A.L.; Haibe, D.N.; Barrett, D.J., Eds.; Society for Mining, Metallurgy, and Exploration: Denver, CO, USA, 2002; pp.1606-1630

4. Habashi, F. A Short History of Hydrometallurgy. Hydrometallurgy 2005, 79, $15-22$. https://doi.org/10.1016/j.hydromet.2004.01.008

5. Sukla, L. B.; Pattanaik, A.; Pradhan, D. Advances in Beneficiation of Low-Grade Bauxite. In Light Metals 2019, The Minerals, Metals \& Materials Series; Chesonis, C., Ed.; Springer Nature Switzerland, 2019; pp. 3-10. https://doi.org/10.1007/978-3-030-05864-7_1

6. Watling, H.R.; Shiers, D.W.; Collinson, D.M. Extremophiles in mineral sulphide heaps: Some bacterial responses to variable temperature, acidity and solution composition. Microorganisms 2015, 3, 364-390. https://doi.org/10.3390/microorganisms3030364

7. Brierley, J.A. A perspective on developments in biohydrometallurgy. Hydrometallurgy 2008, 94, 2-7. https://doi.org/10.1016/j.hydromet.2008.05.014

8. Watling, H.R. The bioleaching of sulphide minerals with emphasis on copper sulphides - A review. Hydrometallurgy 2006, 84, 81-108. https://doi.org/10.1016/j.hydromet.2006.05.001

9. Pradhan, N.; Nathsarma, K. C.; Srinivasa Rao, K.; Sukla, L.B.; Mishra B.K. Heap bioleaching of chalcopyrite: A review. Miner. Eng. 2008, 21, 355-365. https://doi.org/10.1016/j.mineng.2007.10.018

10. Sukla, L.B.; Nathsarma, K.C.; Mahanta, J.R.; Singh, S.; Behera, S.; Srinivas Rao, K.; Subbaiah, T.; Mishra, B.K. Recovery of copper values from bio-heap leaching of low grade Malanjkhand chalcopyrite ore. Korean J. Chem. Eng. 2009, 26, 1668-1674. https://doi.org/10.1007/s11814-009-0271-y

11. Panda, S.; Sanjay, K.; Sukla, L.B.; Pradhan, N.; Subbaiah, T.; Mishra, B.K.; Prasad, M.S.R.; Ray S.K. Insights into heap bioleaching of low grade chalcopyrite ores - A pilot scale study. Hydrometallurgy 2012, 125-126, 157-165. https://doi.org/10.1016/j.hydromet.2012.06.006

12. Kerr, M.; Aurora, E.I. Polymeric Combinations Used as Copper and Precious Metal Heap Leaching Agglomeration Aids. U.S.Patent 5, 833, 937, 1998.

13. Anthony, S.; Purkiss, R. Heap Leaching Base Metals from Oxide Ores. Patent WO2004031422A1, 2004. 
14. Heinen, H.J.; Peterson, D.G.; Lindstrom R.E. Processing Gold Ores Using Heap Leach Carbon Adsorption Methods. Information Circular 8770. U.S. Department of the Interior, Bureau of Mines: Reno, NV, USA. 1978, 1-21.

15. Basov, V. Heap Leach: Mining Breakthrough Technology. Mining.Com Newsletter 2015, 1-4.

16. Mwase, J.M.; Petersen, J.; Eksteen, J.J. A novel sequential heap leach process for treating crushed Plat reef ore. Hydrometallurgy 2014, 141, 97-104. https://doi.org/10.1016/j.hydromet.2013.11.005

17. Sherlock, W.K. Issues affecting heap biooxidation of low-grade refractory gold ore:formation of secondary sulfates, ore lithology, alteration and sulfide mineralogy at gold quarry, Carlin, Nevada. Master's Thesis, University of Nevada, Reno, NA, USA. August 2010.

18. Pingitore, N.E. Extraction and Recovery of Yttrium and Rare Earth Elements. U.S. Patent US20160138133A1. 2016.

19. McCready, R.G.L.; Gould, W.D. Bioleaching of uranium. In Microbial Mineral Recovery; Ehrlich, H.L.; Brierley C.L., Eds.; New York, NY: McGraw-Hill, 1990; pp.107-125.

20. Hedrich, S.; Joulian, C.; Graupner, T.; Schippers, A.; Guézennec, A. Enhanced chalcopyrite dissolution in stirred tank reactors by temperature increase during bioleaching. Hydrometallurgy 2018, 179, 125-131. https://doi.org/10.1016/j.hydromet.2018.05.018

21. Bosecker, K. Bioleaching: metal solubilization by microorganisms. FEMS Microbiol. Rev. 1997, 20, 591604. https://doi.org/10.1111/j.1574-6976.1997.tb00340.x

22. Petersen, J. Heap leaching as a key technology for recovery of values from low-grade ores - A brief overview. Hydrometallurgy 2016, 165, 206-212. https://doi.org/10.1016/j.hydromet.2015.09.001

23. Batty, J.D.; Rorke, G.V. Development and commercial demonstration of the BioCOPTM thermophile process. Hydrometallurgy 2006, 83, 83-89. https://doi.org/10.1016/j.hydromet.2006.03.049

24. Murray, C.; Platzer, W.; Petersen, J. Potential for solar thermal energy in the heap bioleaching of chalcopyritein Chilean copper mining. Miner. Eng. 2017, 100, 75-82. https://doi.org/10.1016/j.mineng.2016.09.022

25. Charikinya, E.; Bradshaw S.M. An experimental study of the effect of microwave treatment on long term bioleaching of coarse, massive zinc sulphide ore particles. Hydrometallurgy 2017, 173, 106-114. https://doi.org/10.1016/j.hydromet.2017.08.001

26. Panda, S.; Biswal, A.; Mishra, S.; Panda, P.K.; Pradhan, N.; Mohapatra, U.; Sukla, L.B.; Mishra, B.K.; Akcil A. Reductive dissolution by waste newspaper for enhanced meso-acidophilic bioleaching of copper from low grade chalcopyrite: A new concept of biohydrometallurgy. Hydrometallurgy 2015, 153, 98-105. https://doi.org/10.1016/j.hydromet.2015.02.006

27. Sukla, L.B.; Swamy, K.M.; Narayana, K.L.; Kar, R.N.; Panchanadikar, V.V. Bioleaching of Sukinda laterite using ultrasonics. Hydrometallurgy 1995, 37, 387-391. https://doi.org/10.1016/0304-386X(94)00031-W.

28. Esther, J.; Pattanaik, A.; Pradhan, N.; Sukla, L.B. Applications of Dissimilatory Iron Reducing Bacteria (DIRB) for recovery of $\mathrm{Ni}$ and $\mathrm{Co}$ from low-grade lateritic nickel ore. Mater. Today Proceed. 2020, 30, 351354. https://doi.org/10.1016/j.matpr.2020.02.167

29. Kaksonen, A.H.; Boxall, N.J.; Gumulya, Y.; Khaleque, H.N.; Morris, C.; Bohu, T.; Cheng, K.Y.; Usher, K.M.; Lakaniemi, A.-M. Recent progress in biohydrometallurgy and microbial characterisation. Hydrometallurgy 2018, 180, 7-25. https://doi.org/10.1016/j.hydromet.2018.06.018

30. Sharma, S.; Rashmitha, C.S.; Pandey, L.M. Synthesis and characterization of methyl acrylamide cellulose nanowhiskers for environmental applications. Lett. Appl. NanoBioScience 2020, 9, 880884. https://doi.org/10.33263/LIANBS91.880884

31. Gu, T; Rastegar, S. O.; Mousavi, S. M.; Li, M.; Zhou M. Advances in bioleaching for recovery of metals and bioremediation of fuel ash and sewage sludge. Bioresour. Technol. 2018, 261, 428-44. https://doi.org/10.1016/j.biortech.2018.04.033

32. Malla, M.A.; Dubey, A.; Yadav, S.; Kumar, A.; Hashem, A.; Abd Allah, E.F. Understanding and Designing the Strategies for the Microbe-Mediated Remediation of Environmental Contaminants Using Omics Approaches. Front. Microbiol. 2018, 9. https://doi.org/10.3389/fmicb.2018.01132

33. Singh, S.; Sukla, L.B.; Goyal S.K. Mine waste \& circular economy. Mater. Today Proceed. 2020, 30, 332339. https://doi.org/10.1016/j.matpr.2020.01.616

34. Samal, DP. K.; Sukla, L.B.; Pattanaik, A.; Pradhan, D. Role of microalgae in treatment of acid mine drainage and recovery of valuable metals. Mater. Today Proceed. 2020, 30, 346-350. https://doi.org/10.1016/j.matpr.2020.02.165

35. Rawlings, D.E. Heavy metal mining using microbes. Annu. Rev. Microbiol. 2002, 56, 65-91. https://doi.org/10.1146/annurev.micro.56.012302.161052

36. Jafari, M.; Abdollahi, H.; Shafaei, S.Z.; Gharabaghi, M.; Jafari, H.; Akcil, A.; Panda, S. Acidophilic bioleaching: a review on the process and effect of organic-inorganic reagents and materials on its efficiency. Min. Proc. Ext. Met. Rev. 2018, 40, 87-107. https://doi.org/10.1080/08827508.2018.1481063

37. Temple, K.L.; Colmer, A.R. The autotrophic oxidation of iron by a new bacterium: Thiobacillus ferrooxidans. J. Bacteriol. 1951, 62, 605-611.

38. Markosyan, G.E. A new iron-oxidizing bacterium-Leptospirillum ferrooxidans nov. gen. nov. sp (in Russian). Biol. J. Armenia 1972, 25, 26-29. 
39. Kelly, D.P.; Wood, A.P. Reclassification of some species of Thiobacillus to the newly designated genera of Acidithiobacillus gen. nov., Halothiobacillus gen. nov. and Thermithiobacillus gen. nov. Int. J. Syst. Evol. Microbiol. 2000, 50, 511-516. https://doi.org/10.1099/00207713-50-2-511

40. Olson, G.J.; Brierley, J.A.; Brierley, C.L. Bioleaching review part B:Progress in bioleaching: applications of microbial processes by the minerals industries. Appl. Microbiol. Biotechnol. 2003, 63, $249-257$. https://doi.org/10.1007/s00253-003-1404-6

41. Johnson, D.B. Extremophiles:acid environments. In Encyclopaedia of Microbiology; Schaechter, M., Eds.; Elsevier, 2009; pp.107-126.

42. Rawlings, D.E.; Coram, N.J.; Gardner, M.N.; Deane, S.M. Thiobacillus caldus and Leptospirillum ferrooxidans are widely distributed in continuous flow biooxidation tanks used to treat a variety of metal containing ores and concentrates. In Biohydrometallurgy and the environment toward the mining of the 21st century Part A; Amils, R.; Ballester, A., Eds.; Elsevier Press, Amsterdam, 1999; pp.777-786.

43. Vian, M.; Creo, C.; Dalmastri, C.; Gionni, A.; Palazzolo, P.; Levi, G. Thiobacillus ferrooxidans selection in continuous culture. In Fundamental and Applied Biohydrometallurgy; Lawrence, R.W.; Branion, R.M.R.; Ebner, H.G., Eds.; Amsterdam: Elsevier, 1986; pp. 395-406.

44. V'asquez, M.; Espejo, R.T. Chemolithotrophic bacteria in copper ores leachedat high sulfuric acid concentration. Appl. Environ. Microbiol. 1997, 63, 332-334.

45. Edwards, K.J.; Bond, P.L.; Gihring, T.M.; Banfield, J.F. An Archaeal iron-oxidizing extreme acidophile important in acid mine drainage. Science 2000, 279, 1796-1799. https://doi.org/10.1126/science.287.5459.1796

46. Johnson, D.B. GenusII Leptospirillum (ex Markosyan 1972) Hippe 2000. In Bergey's manual of systematicbacteriology, 2nd ed.; Garrity, G., Eds.; Springer-Verlag, Berlin, Germany, 2001; pp. 453-457.

47. DeWulf-Durand, P.; Bryant, L.J.; Sly, L.I. PCR-mediated detection of acidophilic, bioleaching-associated bacteria. Appl. Environ. Microbiol. 1997, 63, 2944-2948.

48. Norris,P.R.; Burton,N.P.; Foulis, N.A.M. Acidophiles in bioreactor mineral processing. Extremophiles 2000 , 4, 71-76, https://doi.org/10.1007/s007920050139

49. Huber,H.; Spinnler,C.; Gambacorta,A.; Stetter,K.O. Metallosphaera gen. and sp. nov. represents a new genus of aerobic, metal mobilizing, thermoacidophilic archaebacteria. Syst. Appl. Microbiol. 1989, 12, 3847. https://doi.org/10.1016/S0723-2020(89)80038-4

50. Segerer, A.; Neuner, A.; Kristjansson, J.K.; Stetter, K.O. Acidianus infernus gen. nov., sp. nov., and Acidianus brierleyi comb. nov.: facultatively aerobic, extremely acidophilicthermophilic sulfurmetabolizing archaebacteria. Int. J. Syst. Bacteriol. 1986, 36, 559-564. https://doi.org/10.1099/0020771336-4-559

51. Rastegar, S.O.; Mousavi, S.M.; Rezaei, M.; Shojaosadati, S.A. Statistical evaluation and optimization of effective parameters in bioleaching of metals from molybdenite concentrate using Acidianus brierleyi. J. Ind. Eng. Chem. 2014, 20, 3096-3101. https://doi.org/10.1016/j.jiec.2013.11.049

52. Rasoulnia, P.; Mousavi, S.M.; Rastegar, S.O.; Azargoshasb, H. Fungal leaching of valuable metals from a power plant residual ash using Penicillium simplicissimum: evaluation of thermal pretreatment and different bioleaching methods. Waste Manage. 2016, 52, 309-317. https://doi.org/10.1016/j.wasman.2016.04.004

53. Vakilchap, F.; Mousavi, S.M.; Shojaosadati, S.A. Role of Aspergillus niger in recovery enhancement of valuable metals from produced redmud in Bayer process. Bioresour. Technol. 2016, 218, 991-998. https://doi.org/10.1016/j.biortech.2016.07.059

54. Liao, X.; Sun, S.; Zhou, S.; Ye, M.; Liang, J.; Huang, J.; Guan, Z.; Li, S. A new strategy on biomining of low grade base-metal sulfide tailings. Bioresour. Technol. 2019, 294. https://doi.org/10.1016/j.biortech.2019.122187

55. Marafi, M.; Stanislaus, A.; Furimsky, E. Hand book of Spent Hydroprocessing Catalysts: Regeneration, Rejuvenation, Reclamation, Environment and Safety, $1^{\text {st }}$ ed.; Elsevier, 2010.

56. Falco, L.; Pogliani, C.; Curutchet, G.; Donati, E. A comparison of bioleaching of covellite using pure cultures of Acidithiobacillus ferrooxidans and Acidithiobacillus thiooxidans or a mixed culture of Leptospirillum ferrooxidans and Acidithiobacillus thiooxidans. Hydrometallurgy 2003, 71, 31-36. https://doi.org/10.1016/S0304-386X(03)00170-1

57. Sand, W.; Gehrke, T.; Jozsa, P.G.; Schippers, A. (Bio)chemistry of bacterial leaching-direct vs. indirect bioleaching. Hydrometallurgy 2001, 59, 159-175. https://doi.org/10.1016/S0304-386X(00)00180-8

58. Natarajan, K.A. Bioleaching Mechanisms. In Biotechnology of Metals, 1st ed.; Natarajan, K.A., Ed.; Elsevier, 2018; pp. 49-80. https://doi.org/10.1016/B978-0-12-804022-5.00004-9

59. Tributsch, H. Direct versus indirect bioleaching. Hydrometallurgy 2001, 59, 177-185. https://doi.org/10.1016/S0304-386X(00)00181-X

60. Vera, M.; Schippers, A.; Sand, W. Progress in bioleaching: fundamentals and mechanisms of bacterial metal sulfide oxidation-partA. Appl. Microbiol. Biotechnol. 2013, 97, 7529-7541. https://doi.org/10.1007/s00253-013-4954-2

61. Schippers, A.; Rohwerder, T.; Sand, W. Intermediary sulfur compounds in pyrite oxidation: implications for bioleaching and biodepyritization of coal. Appl. Microbiol. Biotechnol. 1999, 52, 104-110. https://doi.org/10.1007/s002530051495 
62. Schippers, A.; Sand, W. Bacterial leaching of metal sulfides proceeds by two indirect mechanisms via thiosulfate or via polysulfides and sulfur. Appl. Environ. Microbiol. 1999, 65, 319-321. https://doi.org/10.1128/aem.65.1.319-321.1999

63. Rimstidt, J.D.; Vaughan, D.J. Pyrite oxidation: a state-of-the-art assessment of there action mechanism. Geochim. Cosmochim. Acta 2003, 67, 873-880. https://doi.org/10.1016/S0016-7037(02)01165-1

64. Schippers, A. Biogeochemistry of metal sulfide oxidation in mining environments, sediments and soils. In Sulfur biogeochemistry — past and present. Amend, J.P.; Edwards, K.J.; Lyons, T.W., Eds.; Special Paper 379. Geological Society of America, Boulder, CO. 2004; pp. 49-62. https://doi.org/10.1130/0-8137-23795.49

65. Druschel, G.; Borda, M. Commenton "Pyrite dissolution in acidic media" by M. Descostes, P. Vitorge, and C. Beaucaire. Geochim. Cosmochim. Acta 2006, 70, 5246-5250. https://doi.org/10.1016/j.gca.2005.07.023

66. Luther, G.W.III. Pyrite oxidation and reduction: molecular orbital theory considerations. Geochim. Cosmochim. Acta 1987, 51, 3193-3199. https://doi.org/10.1016/0016-7037(87)90127-X

67. Moses, C.O.; Nordstrom, D.K.; Herman, J.S.; Mills, A.L. Aqueous pyrite oxidation by dissolved oxygen and by ferric iron. Geochim. Cosmochim. Acta 1987, 51, 1561-1571. https://doi.org/10.1016/00167037(87)90337-1

68. Druschel, G.K. Sulfur biogeochemistry: kinetics of intermediate sulfur species reactions in the environment. PhD thesis, University of Wisconsin 2002.

69. Balci, N.; Shanks, W.C.III.; Mayer, B.; Mandernack, K.W. Oxygen and sulfur isotope systematics of sulfate produced during bacterial and abiotic oxidation of pyrite. Geochim. Cosmochim. Acta 2007, 71, 3796-3811. https://doi.org/10.1016/j.gca.2007.04.017

70. Hackl, R.P.; Dreisinger, D.B.; Peters, E.; King, J.A. Passivation of chalcopyrite during oxidative leaching in sulfate media. Hydrometallurgy 1995, 39, 25-48. https://doi.org/10.1016/0304-386X(95)00023-A

71. Smart, R.S.C.; Jasieniak, M.; Prince, K.E.; Skinner, W.M. SIMS studies of oxidation mechanisms and polysulfide formation in reacted sulfide surfaces. Miner. Eng. 2000, 13, 857-870. https://doi.org/10.1016/s0892-6875(00)00074-1

72. McGuire, M.M.; Edwards, K.J.; Banfield, J.F.; Hamers, R.J. Kinetics, surface chemistry, and structural evolution of microbially mediated sulfide mineral dissolution. Geochim. Cosmochim. Acta 2001, 65, 12431258. https://doi.org/10.1016/S0016-7037(00)00601-3

73. Thomas, J.E., Skinner, W.M.; Smart, R.S.C. A mechanism to explain sudden changes in rates and products for pyrrhotite dissolution in acid solution. Geochim. Cosmochim. Acta 2001, 65, 1-12. https://doi.org/10.1016/s0016-7037(00)00503-2

74. Thurston, R.S.; Mandernack, K.W.; Shanks, W.C.III. Laboratory chalcopyrite oxidation by Acidithiobacillus ferrooxidans: oxygen and sulfur isotope fractionation. Chem. Geol. 2010, 269, 252-261. https://doi.org/10.1016/j.chemgeo.2009.10.001

75. Balci, N.; Mayer, B.; Shanks, W.C.III.; Mandernack, K.W. Oxygen and sulfur isotope systematics of sulfate produced during abiotic and bacterial oxidation of sphalerite and elemental sulfur. Geochim. Cosmochim. Acta 2012, 77, 335-351. https://doi.org/10.1016/j.gca.2011.10.022

76. Pattanaik, A.; Sukla, L.B., Pradhan, D.; Samal DP. K. Microbial mechanism of metal sulfide dissolution. Mater. Today Proceed. 2020, 30, 326-331. https://doi.org/10.1016/j.matpr.2020.01.615

77. Gumulya, Y.; Boxall, N.J.; Khaleque, H.N.; Santala, V.; Carlson, R.P.; Kaksonen, A.H. In a Quest for Engineering Acidophiles for Biomining Applications: Challenges and Opportunities. Genes 2018, 9 , https://doi.org/10.3390/genes9020116

78. Holmes, D.S.; Bonnefoy, V. Genetic and bioinformatic insights into iron and sulfur oxidation mechanisms of bioleaching organisms. In Biomining, 1st ed.; Rawlings, D.E.; Johnson, D.B., Eds.; Springer: Berlin/Heidelberg, Germany, 2007; pp. 281-307. https://doi.org/10.1007/978-3-540-34911-2_14

79. Bonnefoy, V. Bioinformatics and genomics of iron- and sulfur-oxidizing acidophiles. In Geomicrobiology: Molecular and Environmental Perspective, 1st ed.; Barton, L.; Mandl, M.; Loy, A., Eds.; Springer: Dordrecht, The Netherlands, 2010; pp. 169-192. https://doi.org/10.1007/978-90-481-9204-5_8

80. Amouric, A.; Brochier-Armanet, C.; Johnson, D.B.; Bonnefoy, V.; Hallberg, K.B. Phylogenetic and genetic variation among $\mathrm{Fe}(\mathrm{II})$-oxidizing Acidithiobacilli supports the view that these comprise multiple species with different ferrous iron oxidation pathways. Microbiology 2011, 157, 111-122. https://doi.org/10.1099/mic.0.044537-0

81. Mi, S.; Song, J.; Lin, J.Q.; Che, Y.Y.; Zheng, H.J.; Lin, J.Q. Complete genome of Leptospirillum ferriphilum Ml-04 provides insight into its physiology and environmental adaptation. J. Microbiol. 2011, 49, 890-901. https://doi.org/10.1007/s12275-011-1099-9

82. Dopson, M.; Baker-Austin, C.; Bond, P.L. Analysis of differential protein expression during growth states of Ferroplasma strains and insights into electron transport for iron oxidation. Microbiology 2005, 151, 41274137. https://doi.org/10.1099/mic.0.28362-0

83. Bathe, S.; Norris, P.R. Ferrousiron- and sulfur-induced genes in Sulfolobus metallicus. Appl. Environ. Microbiol. 2007, 73, 2491-2497. https://doi.org/10.1128/AEM.02589-06 
84. Auernik, K.S.; Kelly, R.M. Identification of components of electron transport chains in the extremely thermoacidophilic crenarchaeon Metallosphaera sedula through iron and sulfur compound oxidation transcriptomes. Appl. Environ. Microbiol. 2008, 74, 7723-7732. https://doi.org/10.1128/AEM.01545-08

85. Rohwerder, T.; Sand, W. The sulfane sulfur of persulfides is the actual substrate of the sulfur-oxidizing enzymes from Acidithiobacillus and Acidiphilium spp. Microbiology 2003, 149, 1699-1710. https://doi.org/10.1099/mic.0.26212-0

86. Rawlings, D.E. Characteristics and adaptability of iron- and sulfur-oxidizing microorganisms used for there covery of metals from minerals and their concentrates. Microb. Cell Fact. 2005, 4. https://doi.org/10.1186/1475-2859-4-13

87. Rohwerder, T.; Gehrke, T.; Kinzler, K., Sand, W. Bioleaching review partA: progress in bioleaching: fundamentals and mechanisms of bacterial metal sulfide oxidation. Appl. Microbiol. Biotechnol. 2003, 63, 239-248. https://doi.org/10.1007/s00253-003-1448-7

88. Bellenberg, S.; Leon-Morales, C.F.; Sand, W.; Vera, M. Visualization of capsular polysaccharide induction in Acidithiobacillus ferrooxidans. Hydrometallurgy $\mathbf{2 0 1 2}, \quad 129-130, \quad 82-89$. https://doi.org/10.1016/j.hydromet.2012.09.002

89. Vera, M.; Krok, B.; Bellenberg, S.; Sand, W.; Poetsch, A. Shotgun proteomics study of early biofilm formation process of Acidithiobacillus ferrooxidans ATCC23270 on pyrite. Proteomics 2013, 13, 11331144. https://doi.org/10.1002/pmic.201200386

90. Gehrke, T.; Hallmann, R.; Kinzler, K.; Sand, W. The EPS of Acidithiobacillus ferrooxidans-a model for structure-function relationships of attached bacteria and their physiology. Water Sci. Technol. 2001, 43, 159-167. https://doi.org/10.2166/wst.2001.0365

91. Jerez, C.A. The use of genomics, proteomics and other OMICS technologies for the global understanding of biomining microorganisms. Hydrometallurgy $2008, \quad$ 2008, https://doi.org/10.1016/j.hydromet.2008.05.032

92. Acuña, J.; Rojas, J.; Amaro, A.M.; Toledo, H., Jerez, C.A. Chemotaxis of Leptospirillum ferrooxidans and other acidophilic chemolithotrophs: comparison with the Escherichia coli chemosensory system. FEMS Microbiol. Lett. 1992, 75, 37-42. https://doi.org/10.1111/j.1574-6968.1992.tb05390.x

93. Jerez, C.A. Chemotactic transduction in biomining microorganisms. Hydrometallurgy 2001, 59, 347-356. https://doi.org/10.1016/S0304-386X(00)00177-8

94. Meyer, G.; Schneider-Merck, T.; Böhme, S., Sand, W. A simple method for investigations on the chemotaxis of A. ferrooxidans and D. vulgaris. Acta Biotechnol. 2002, 22, 391-399. https://doi.org/10.1002/15213846(200207)22:3/4<391::AID-ABIO391>3.0.CO;2-6

95. Farah, C.; Vera, M.; Morin, D.; Haras, D.; Jerez, C.A.; Guiliani, N. Evidence for a functional quorum-sensing type AI-1 system in the extremophilic bacterium Acidithiobacillus ferrooxidans. Appl. Environ. Microbiol. 2005, 71, 7033-7040. https://doi.org/10.1128/aem.71.11.7033-7040.2005

96. Valenzuela, L.; Chi, A.; Beard, S.; Orell, A.; Guiliani, N.; Shabanowitz, J.; Hunt, D.F.; Jerez, C.A. Genomics, metagenomics and proteomics in biomining microorganisms. Biotechnol. Adv. 2006, 24, 197211. https://doi.org/10.1016/j.biotechadv.2005.09.004

97. Rivas, M.; Seeger, M.; Jedlicki, E.; Holmes, D.S. Second acyl homoserine lactone production system in the extreme acidophile Acidithiobacillus ferrooxidans. Appl. Environ. Microbiol. 2007, 73, 3225-3231. https://doi.org/10.1128/AEM.02948-06

98. Ruiz, L.M.; Sand, W.; Jerez, C.A.; Guiliani, N. C-di-GMP pathway in Acidithiobacillus ferrooxidans: analysis of putative diguanylate cyclases (DGCs) and phospho diesterases (PDEs) bifunctional proteins. $A d v$. Mat. Res. 2007, 20-21, 551-555. https://doi.org/10.4028/www.scientific.net/AMR.20-21.551

99. Barreto, M.; Jedlicki, E.; Holmes, D.S. Identification of a gene cluster for the formation of extracellular polysaccharide precursors in the chemolithoautotroph Acidithiobacillus ferrooxidans. Appl. Environ. Microbiol. 2005, 71, 2902-2909. https://doi.org/10.1128/AEM.71.6.2902-2909.2005

100. DeSousa, C.S.; Hassan, S.S.; Pinto, A.C.; Silva, W.M.; DeAlmeida, S.S.; DeCastroSoares, S.; Azevedo, M.S.P.; Rocha, C.S.; Barh, D.; Azevedo, V. Microbial Omics: Applications in Biotechnology. In Omics Technologies and Bio-engineering: Towards Improving Quality of Life, 1st ed.; Barh, D.; Azevedo, V., Eds.; Elsevier Inc., 2018; pp. 3-20. https://doi.org/10.1016/B978-0-12-815870-8.00001-2

101. Selkov, E.; Overbeek,R.; Kogan, Y.; Chu, L.; Vonstein, V.; Holmes, D.; Silver, S.; Haselkorn, R.; Fonstein, M. Functional analysis of gapped microbial genomes: aminoacid metabolism of Thiobacillus ferrooxidans. PNAS 2000, 97, 3509-3514. https://doi.org/10.1073/pnas.97.7.3509

102. Martinez, P.; Vera, R.; Bobadilla-Fazzini, A. Omics on bioleaching: current and future impacts. Appl. Microbiol. Biotechnol. 2015, 99, 8337-8350. https://doi.org/10.1007/s00253-015-6903-8

103. Christel, S.; Herold, M.; Bellenberg, S.; ElHajjami, M.; Buetti-Dinh, A.; Pivkin, IV.; Sand, W.; Wilmes, P.; Poetsch, A.; Dopson, M. Multiomics reveals the lifestyle of the acidophilic, mineral-oxidizing model species Leptospirillum ferriphilum ${ }^{\mathrm{T}}$. Appl. Environ. Microbiol. 2018, 84, https://doi.org/10.1128/AEM.02091-17

104. Buetti-Dinh, A.; Herold, M.; Christel, S.; ElHajjami, M.; Delogu, F.; Ilie, O.; Bellenberg, S.; Wilmes, P.; Poetsch, A.; Sand, W.; Vera, M.; Pivkin, I.V.; Friedman, R.; Dopson, M. Reverse engineering directed gene regulatory networks from transcriptomics and proteomics data of biomining bacterial communities with 
approximate Bayesian computation and steady-state signalling simulations. BMC Bioinformatics 2020, 21. https://doi.org/10.1186/s12859-019-3337-9

105. Buetti-Dinh, A.; Herold, M.; Christel, S.; ElHajjami, M.; Bellenberg, S.; Ilie, O.; Wilmes, P.; Poetsch, A.; Sand, W.; Vera, M.; Pivkin, I.V.; Dopson, M. Systems biology of acidophile biofilms for efficient metal extraction. Sci. Data 2020, 7. https://doi.org/10.1038/s41597-020-0519-2

106. Zhou, S.; Gan, M.; Zhu, J.; Liu, X.; Qiu, G. Assessment of Bioleaching Microbial Community Structure and Function Based on Next-Generation Sequencing Technologies. Minerals 2018, 8. https://doi.org/10.3390/min8120596

107. Natarajan, K.A. Microbiological Aspects of Leaching Microorganisms. In Biotechnology of Metals, 1st ed.; Natarajan, K.A., Ed.; Elsevier, 2018; pp. 29-47. https://doi.org/10.1016/B978-0-12-804022-5.00003-7

108. Hawkes, R.B.; Franzmann, P.D.; O’Hara, G.; Plumb, J.J. Ferroplasma cupricumulans sp. nov., a novel moderately thermophilic, acidophilic archaeon isolated from an industrial-scale chalcocite bioleach heap. Extremophiles 2006, 10, 525-530. https://doi.org/10.1007/s00792-006-0527-y

109. Golyshina, O.V.; Yakimov, M.M.; Lünsdorf, H.; Ferrer, M.; Nimtz, M.; Timmis, K.N.; Wray, V.; Tindall, B.J.; Golyshin, P.N. Acidiplasma aeolicum gen. nov., sp. nov., a euryarchaeon of the family Ferroplasmaceae isolated from a hydrothermal pool, and transfer of Ferroplasma cupricumulans to Acidiplasma cupricumulans comb. nov. Int. J. Syst. Evol. 2009, 59, 2815-2823. https://doi.org/10.1099/ijs.0.009639-0

110. Coram-Uliana, N.J.; vanHille, R.P.; Kohr, W.J.; Harrison, S.T.L. Development of a method to assay the microbial population in heap bioleaching operations. Hydrometallurgy 2006, 83, 237-244. https://doi.org/10.1016/j.hydromet.2006.03.054

111. Maass, A.; Aravena, A.; Gonzalez, M.; Martinez, S.; Parada, P.; Ehrenfeld, K. Method for the design of oligonucleotides for molecular biology techniques.U.S. Patent No. US7853408B2, 2010.

112. Ehrenfeld, K.; Ugalde, J.; Aravena, A.; Loira, N.; Maass, A.; Parada, P.; Badilla, R. Array of nucleotidic sequences for the detection and identification of genes that codify proteins with activities relevant in biotechnology present in a microbiological sample, and method for using this array. U.S. Patent No. US8207324B2, 2012.

113. Parada, P.; Ehrenfeld, N.; Pacheco, I.; Maass, A.; Aravena, A.; Gonzalez, M.; Martinez, S. Method for the identification and quantification of microorganisms useful in biomining processes. U.S. Patent No. US20110136125A1, 2013.

114. Ghosh, S.; Das A. P. Metagenomic insights into the microbial diversity in manganese contaminated mine tailings and their role in biogeochemical cycling of manganese. Sci. Rep. 2018, 8. https://doi.org/10.1038/s41598-018-26311-w

115. Chung, A.P.; Coimbra, C.; Farias, P.; Francisco, R.; Branco, R.; Simão, F.V.; Gomes, E.; Pereira, A.; Vila, M.C.; Fiúza, A.; Mortensen, M.S.; Sørensen, S.J.; Morais, P.V. Tailings microbial community profile and prediction of its functionality in basins of tungsten mine. Sci. Rep. 2019, 9. https://doi.org/10.1038/s41598019-55706-6

116. Acosta, M.; Beard, S.; Ponce, J.; Vera, M.; Mobarec, J.C.; Jerez, C.A. Identification of putative sulfur transferase genes in the extremophilic Acidithiobacillus ferrooxidans ATCC23270genome: structural and functional characterization of the proteins. OMICS 2005, 9, 13-28. https://doi.org/10.1089/omi.2005.9.13

117. Bruscella, P.; Appia-Ayme, C.; Levican, G.; Ratouchniak, J.; Jedlicki, E.; Holmes, D.S.; Bonnefoy, V. Differential expression of two bc1 complexes in the strict acidophilic chemolithoautotrophic bacterium Acidithiobacillus ferrooxidans suggests a model for their respective roles in iron or sulfur oxidation. Microbiology 2007, 153, 102-110. https://doi.org/10.1099/mic.0.2006/000067-0

118. Quatrini, R.; Appia-Ayme, C.; Denis, Y.; Jedlicki, E.; Holmes, D.S.; Bonnefoy, V. Extending the models for iron and sulfur oxidation in the extreme acidophile Acidithiobacillus ferrooxidans. BMC Genomics 2009 , 10. https://doi.org/10.1186/1471-2164-10-394

119. Mardanov, A.V.; Svetlitchnyi, V.A.; Beletsky, A.V.; Prokofeva, M.I.; BonchOsmolovskaya, E.A.; Ravin, N.V.; Skryabin, K.G. The genome sequence of the crenarchaeon Acidilobus saccharovorans supports a new order, Acidilobales, and suggests an important ecological role in terrestrial acidic hotsprings. Appl. Environ. Microbiol. 2010, 76, 5652-5657. https://doi.org/10.1128/AEM.00599-10

120. You, X.Y.; Liu, C.; Wang, S.Y.; Jiang, C.Y.; Shah, S.A.; Prangishvili, D.; She, Q.; Liu, S.J.; Garrett, R.A. Genomic analysis of Acidianus hospitalis W1 a host for studying crenarchaeal virus and plasmid lifecycles. Extremophiles 2011, 15, 487-497. https://doi.org/10.1007/s00792-011-0379-y

121. Hold, C.; Andrews, B.A.; Asenjo, J.A. A stoichiometric model of Acidithiobacillus ferrooxidans ATCC23270 for metabolic flux analysis. Biotechnol. Bioeng. 2009, 102, 1448-1459. https://doi.org/10.1002/bit.22183

122. Merino, M.P.; Andrews, B.A.; Asenjo, J.A. Stoichiometric model and metabolic flux analysis for Leptospirillum ferrooxidans. Biotechnol. Bioeng. 2010, 107, 696-706. https://doi.org/10.1002/bit.22851

123. Bobadilla-Fazzini, R.A.; Cortés, M.P.; Padilla, L.; Maturana, D.; Budinich, M.; Maass, A.; Parada, P. Stoichiometric modeling of oxidation of reduced inorganic sulfur compounds (Riscs) in Acidithiobacillus thiooxidans. Biotechnol. Bioeng. 2013, 110, 2242-2251. https://doi.org/10.1002/bit.24875 
124. Merino, M.P.; Andrews, B.A.; Asenjo, J.A. Stoichiometric model and flux balance analysis for a mixed culture of Leptospirillum ferriphilum and Ferroplasma acidiphilum. Biotechnol. Prog. 2015, 31, 307-315. https://doi.org/10.1002/btpr.2028

125. Chen, L.; Ren, Y.; Lin, J.; Liu, X.; Pang, X.; Lin, J. Acidithiobacillus caldus sulfur oxidation model based on transcriptome analysis between the wild type and sulfur oxygenase reductase defective mutant. PLoS One 2012, 7. https://doi.org/10.1371/journal.pone.0039470

126. Levicán, G.; Ugalde, J.A.; Ehrenfeld, N.; Maass, A.; Parada, P. Comparative genomic analysis of carbon and nitrogen assimilation mechanisms in three indigenous bioleaching bacteria: predictions and validations. BMC Genomics 2008, 9. https://doi.org/10.1186/1471-2164-9-581

127. Mangold. S.; Valdés, J.; Holmes, D.S.; Dopson, M. Sulfur metabolism in the extreme acidophile Acidithiobacillus caldus. Front. Microbiol. 2011, 2. https://doi.org/10.3389/fmicb.2011.00017

128. Justice, N.B.; Norman, A.; Brown, C.T.; Singh, A.; Thomas, B.C.B.J. Comparison of environmental and isolate Sulfobacillus genomes reveals diverse carbon, sulfur, nitrogen, and hydrogen metabolisms. BMC Genomics 2014, 15. https://doi.org/10.1186/1471-2164-15-1107

129. Guo, X.; Yin, H.; Liang, Y.; Hu, Q., Zhou, X.; Xiao, Y.; Ma, L.; Zhang, X.; Qiu, G.L.X. Comparative Genome Analysis Reveals Metabolic Versatility and Environmental Adaptations of Sulfobacillus thermosulfidooxidans Strain ST. PLoS One 2014, 9. https://doi.org/10.1371/journal.pone.0099417

130. Orellana, L.H.; Jerez, C.A. A genomic island provides Acidithiobacillus ferrooxidans ATCC 53993 additional copper resistance: a possible competitive advantage. Appl. Microbiol. Biotechnol. 2011, 92, 761767. https://doi.org/10.1007/s00253-011-3494-x

131. Travisany, D.; Cortés, M.P.; Latorre, M.; DiGenova, A.; Budinich, M.; Bobadilla-Fazzini, R.A.; Parada, P.; González, M.M.A. A new genome of Acidithiobacillus thiooxidans provides insights into adaptation to a bioleaching environment. Res. Microbiol. 2014, 165, 743-752. https://doi.org/10.1016/j.resmic.2014.08.004

132. Guo, L.; Brügger, K.; Liu, C.; Shah, S.A.; Zheng, H.; Zhu, Y.; Wang, S.; Lillestøl, R.K.; Chen, L.; Frank, J.; Prangishvili, D.; Paulin, L.; She, Q.; Huang, L.; Garrett, R.A. Genome analyses of icelandic strains of Sulfolobus islandicus, model organisms for genetic and virus-host interaction studies. J. Bacteriol. 2011, 193, 1672-1680. https://doi.org/10.1128/JB.01487-10

133. Valdés, J.; Cárdenas, J.P.; Quatrini, R.; Esparza, M.; Osorio, H.; Duarte, F.; Lefimil, C.; Sepulveda, R.; Jedlicki, E.; Holmes, D.S. Comparative genomics begins to unravel the ecophysiology of bioleaching. Hydrometallurgy 2010, 104, 471-476. https://doi.org/10.1016/j.hydromet.2010.03.028

134. Auernik, K.S.; Maezato, Y.; Blue, P.H.; Kelly, R.M. Genome sequence of the metal mobilizing, extremely thermoacidophilic archaeon Metallosphaera sedula provides insights into bioleaching metabolism. Appl. Environ. Microbiol. 2008, 74, 682-692. https://doi.org/10.1128/AEM.02019-07

135. Gygi, S.P.; Corthals, G.L.; Zhang, Y.; Rochon, Y.; Aebersold, R. Evaluation of two-dimensional gel electrophoresis-based proteome analysis technology. PNAS 2000, 97, 9390-5. https://doi.org/10.1073/pnas.160270797

136. Seeger, M.; Jerez, C.A. Response of Thiobacillus ferrooxidans to phosphate limitation. FEMS Microbiol. Rev. 1993, 11, 37-42. https://doi.org/10.1111/j.1574-6976.1993.tb00264.x

137. Vera, M.; Guiliani, N.; Jerez, C.A. Proteomic and genomic analysis of the phosphate starvation response of Acidithiobacillus ferrooxidans. Hydrometallurgy 2003, 71, 125-132. https://doi.org/10.1016/S0304386X(03)00148-8

138. Novo, M.T.; Junior, O.G.; Ottoboni, L.M. Protein profile of Acidithiobacillus ferrooxidans exhibiting different levels of tolerance to metal sulfates. Curr. Microbiol. 2003, 47, 492-496. https://doi.org/10.1007/s00284-003-4096-3

139. Ramirez, P.; Guiliani, N.; Valenzuela, L., Beard, S.; Jerez, C.A. Differential protein expression during growth of Acidithiobacillus ferrooxidans on ferrous iron, sulfur compounds, or metal sulfides. Appl. Environ. Microbiol. 2004, 70, 4491-4498. https://doi.org/10.1128/AEM.70.8.4491-4498.2004

140. Chi, A.; Valenzuela, L.; Beard, S.; Mackey, A.J.; Shabanowitz, J.; Hunt, D.F.; Jerez, C.A. Periplasmic proteins of the extremophile Acidithiobacillus ferrooxidans. Mol. Cell Proteomics 2007, 6, 2239-2251. https://doi.org/10.1074/mcp.M700042-MCP200

141. Almárcegui, R.J.; Navarro, C.A.; Paradela, A.; Albar, J.P.; Bernath, D.V.; Jerez, C.A. New copper resistance determinants in the extremophile Acidithiobacillus ferrooxidans: a quantitative proteomic analysis. $J$. Proteome Res. 2014, 13, 946-960. https://doi.org/10.1021/pr4009833

142. Bellenberg, S; Huynh, D.; Poetsch, A.; Sand, W.; Vera, M. Proteomics Reveal Enhanced Oxidative Stress Responses and Metabolic Adaptation in Acidithiobacillus ferrooxidans Biofilm Cells on Pyrite. Front. Microbiol. 2019, 10. https://doi.org/10.3389/fmicb.2019.00592

143. Pathak, J.; Sonker, A.S.; Rajneesh; Singh, V.; Kumar, D.; Sinha, R.P. Synthesis of silver nanoparticles from extracts of Scytonema geitleri HKAR-12 and their in vitro antibacterial and antitumor potentials. Lett. Appl. NanoBioScience 2019, 8, 576-585. https://doi.org/10.33263/LIANBS83.576585

144. Logan, T.C.; Seal, T.; Brierley, J.A. Whole-ore heap biooxidation of sulfidic gold-bearing ores. In Biomining, 1st ed.; Rawlings, D.E.; Johnson, D.B., Eds.; Springer: Berlin/Heidelberg, Germany, 2007; pp. 113-138. https://doi.org/10.1007/978-3-540-34911-2_6 
145. Renman, R.; Xingyu, L.; Gang, Z.; Jinghe, C.; Jiankang, W.; Dianzuo, W. Industrial practice of a distinct bioleaching system operated at low $\mathrm{pH}$, high ferric concentration, elevated temperature and low redox potential for secondary copper sulphide. Hydrometallurgy 2011, 108, 130-135. 10.1016/j.hydromet.2011.03.008 